\title{
Evaluation of open-source learning management systems (LMS) using design science research methodology
}

\author{
Nandini Kajla, Karthik Naik, and Pawan Kumar* \\ RobozX (Proprietorship Firm), E-399, Sector 29, 136118 Kurukshetra, India
}

\begin{abstract}
The advent of the internet and its easy accessibility to the people has impacted various sectors in the world. One of the major transformations can be clearly seen in the education system. There is an emergence of online education and various courses, video lectures, and test series etc. are now available online to assist the education. The outbreak of the COVID-19 pandemic, which has forced the world to work from home, has accelerated the digital transformation around the globe. These circumstances lead to a strong movement towards work and school / learning from home. In case of school / learning from home, for online education to exist, many open-source learning management systems (LMS), e.g. Moodle, Canvas, OpenOlat and ILIAS, are available and are being used. However, they only partially meet the needs of this fastchanging education industry. Hence, it makes total sense to carry out a scientific evaluation of available LMS in order to conclude a gap analysis. Design science research methodology has been used in this paper for evaluation of selected LMS.
\end{abstract}

Keywords: Open Source Learning Management System (LMS), e-Learning, Design Science Research.

\section{Introduction}

Over the past decade, the impact of the use of internet in education has grown steadily, and new technologies have improved student learning. Through the use of online learning tools, student education can be easily adapted to local and time constraints. Therefore, students can access information at anytime and anywhere, either in libraries or during lectures. Distance learning is expensive, and cost-effectiveness becomes even more important as institutions become major providers of basic education. The most important cost of learning grades depending on traditional learning areas can be eliminated with the wide range of Open Source Software. The general use of open-source software not just for higher education, but also for primary and secondary education, will provide the development of learning tools and increase the quality of education. According to the literature review, not much research has been done on comparing open-source learning management systems in primary and secondary education. So, the education industry is seeking for research about LMS platforms which have the potential to revolutionize the education system of the world and to take advantage of the internet technology which is available easily today. From analyzing the past researches in LMS (Cavus \& Zabadi, 2014; Fathema, Shannon, \& Ross, 2015; Subramanian, Zainuddin, Alatawi, Javabdeh, \& Hussin, 2014; Anaraki, 2004; de Oliveira, de Almeida Cunha, \& Nakayama, 2015; 


\section{World Conference on EDUCATION and TEACHING}

Dobre, 2015) to comparing the different features of LMS platforms, this research examines and compares different vendor analysis, product analysis, and various features of LMS platforms.

This paper is organized in 5 sections. The previous section has covered the background and motivation behind this research. In the next section, we discuss the research methodology that we have used during our research. Later, theoretical foundation gives an overview of past researches which have been already done in the past years regarding the best LMS, their features, comparison on the basis of adaptivity, functionality etc. In the same section, we also compare 10 famous LMS and present a comprehensive research which has been done regarding the vendor analysis and product analysis. At last, before the conclusion section, we present a rationale for selecting the 6 most popular LMS and compare them on the basis of their communication tools, productivity tools etc.

\section{Research methodology}

The research methodology used for this study is design science research. In this method, research can be done by following these five appropriate steps (Hevner \& Chatterjee, 2010):

Step 1: Problem awareness: Awareness can arise from new developments and technologies which enter the industry. The problem can be identified by book reviews, experience in practice, discussion with colleagues etc. The main purpose of this step is to identify the actual problem/topic for research. Step 2: Suggestion: This step involves creative thinking and suggesting ideas based on existing information or on the basis of ideas of the problem area, proper research methodology. Suggestions from existing literature research or explanatory research can be very helpful. Step 3: Development: This is a major part of design in architectural science research. Art objects advanced can be intangible (build, models, or methods) or can be seen in type of computer and hardware software. Step 4: Testing: In this step partial or fully effective use is tested using action research, controlled experiments, simulations, or conditions. We will not present this step in this paper because of space constraints. Step 5: Conclusion: This step marks the suspension of the project and we have the results of the research with us.

\section{Theoretical foundation}

\subsection{Research objective and research questions}

In particular, the research objective of this research has the following aspects: Objective 1: Examine and compare different existing open-source LMS (vendor analysis, product analysis and different features of LMS platforms). Objective 2: Make comparisons of these features among the 6 most popular selected LMS and their user interface. However, the user interface comparison is out of scope of this paper due to space constraints.

\subsection{Past researches}

There have been many researches in the field of online LMS. Some of the selected research papers have been summarized below. 


\subsubsection{Do Learning Management Systems Really Manage Learning? (Bhattacharyya, 2020)}

This research discusses all the ideal features which must be present in LMS for effective learning and teaching. This research explores science of learning and development, foundational learning theories, and popular pedagogical approaches to help educators to design online and blended learning experiences for students. This research segregates the features of LMS into 8 parts: student learning productivity suite, teacher tools aligned to learning science, behaviorism, cognitivism, constructivism, personalized learning, project-based learning, and social/emotional learning. It recommends that the teachers decide if they want to use one of the popular or generic LMS or whether they need more support implementing particular approaches in a specialized LMS. It also recommends that all LMS should support more student-oriented learning.

\subsubsection{A Comparative Study Between E-Learning Features (Al-Ajlan, 2012)}

This research compares different LMS on the basis of various features like learner tools, support tools, technical specifications, productivity tools, course delivery tools, pricing/licensing, student involvement tools, curriculum design. The main aim of this research is to study, analyze, and explore the right decision when choosing a suitable platform to meet the requirements of the students. According to the research, Moodle is the most user-friendly and flexible free open-source courseware product available all over the world.

\subsubsection{A Comparison of Open-Source Learning Management Systems (Cavus \& Zabadi, 2014)}

This paper compares different LMS focuses on the basis of communication tools. It compares the whiteboard/video services, discussion forums, file exchange/internal mail, online journal mail, and real live chat features. The main aim of this research is to find a platform which can fulfill all the requirements of the instructors. This paper mainly focuses on LMS like Atutor, Claroline, Dokeos, ILIAS, Moodle, and Sakai. The study showed that Moodle and Atutor have the best communication tools with a user-friendly interface.

\subsubsection{Expanding the Technology Acceptance Model (TAM) to Examine Faculty Use of Learning Management Systems (LMSs) in Higher Education Institutions (Fathema, Shannon, \& Ross, 2015)}

LMS in higher education institutions: Universities have made significant investments in the use of LMS to simplify their teaching processes. However, these systems are not used by smart members to the best of their ability. To address this issue, this study investigated factors affecting the performance of LMS members and the use of faculty members, focusing on userrelated variables and their important role in determining attitudes toward LMS. This study focuses on the factors that affect the faculty members' attitudes toward LMS and determine the underlying causal relationships among the factors using the proposed extension of the original TAM framework. The results of this study show that system quality (SQ) and faculty perceived selfefficacy (PSE) have a significant positive effect on perceived ease of use (PEOU) and perceived usefulness (PU) of LMS. It also shows some effect of facilitating conditions (FC) on attitudes (ATT) toward using technology and perceived ease of use (PEOU). 


\subsubsection{A Study of Comparison between Moodle and Blackboard Based on Case Studies for Better LMS (Subramanian, Zainuddin, Alatawi, Javabdeh, \& Hussin, 2014)}

This study presents the effectiveness of using Moodle and Blackboard in LMS on students and learners to enhance their learning and understanding. This paper shows that Moodle gave the best results as an LMS but still has room for improvement. Although Blackboard and Moodle have different features, it depends on the preference of the user.

\subsubsection{Learning Management System (LMS) Based on Moodle to Improve Students} Learning Activity (Simanullang \& Rajagukguk, 2020)

This study is a quasi-experiment study conducted with the study to determine the effect of sample treatment in this study on students. The objectives of this study are to look at student learning activities that are taught online using Moodle-based LMS applications. The research study suggests that the Moodle-based LMS can increase student learning activities.

\subsubsection{Electronic Learning Management System: Relevance, Challenges, and Preparedness (Khan, 2020)}

The physical classroom-based education industry has taken a revolutionary step of shifting to virtual classrooms due to the Corona pandemic (COVID-19). The outbreak of COVID-19 was so abrupt that many institutions and students were not even aware of the minor or major effect of the disease worldwide. The result was a complete standstill for a couple of days. There was ambiguity around the world in terms of how to carry on the education in schools. But thanks to LMS platforms it is possible to carry out education in the days of the pandemic. The study concludes that distance learning is the only way to continue education in the time of COVID-19. But, proper training for human resource and institutional preparedness is unavoidable and one has to suffer its consequences.

\subsubsection{Benefits of Learning Management System (LMS) in Indian Education (Kulshrestha \& Kant, 2013)}

This research talks about how academic institutions are struggling hard to find the right combination of students, faculties, protocols and systems to manage their learning programs. LMS are becoming an interface for handling course registration, managing course contents, assessing students through assignments, conducting quizzes and exams for smooth functioning of institute administration, evaluation and report generation. "In general, LMS/e-learning serves as a means for acquiring the knowledge using the help of technologies, e.g. internet and interactive-based technologies, over the traditional ways; thereby enables learning over a wide spectrum with higher efficiency." (Kulshrestha \& Kant, 2013) In this paper we see that the LMS works as a lever for broader improvement of teaching and learning. The paper shows the obstruction for LMS deployment: "Availability of infrastructure like internet, computer is major challenge, power source is necessary during e-learning study, handwriting becomes bad due to overuse of keyboard, student tardiness is often seen if class contents are available online, overuse of computer can damage student's eyes." (Kulshrestha \& Kant, 2013)

3.2.9 Learning Management Systems (LMS) AND E-Learning Management: An Integrative Review And Research Agenda (de Oliveira, de Almeida Cunha, \& Nakayama, 2015)

The purpose of this paper is to analyze the literature available on the use of the LMS for elearning managers, seeking to introduce research opportunities in the field. Comprehensive 
literature reviews were conducted based on the Web of Science, Scopus, Ebsco and Scielo, where 78 references, 25 of which were complete papers, were found. By completing the repetition, there were 14 papers left, which formed a research portfolio. After reading the articles, several papers were selected by us for the analysis that fit the research objectives. To show the aspects that may characterize LMS in e-learning management, we used the categories classifying them into interface, navigation, evaluation, didactic resources, communication/interaction, coordination and administrative support based on the following order: keywords, abstracts and conclusions of the papers analyzed.

\subsubsection{Comparative Analysis of Various Learning Management Systems for Academe in India (Karthik, 2018)}

This paper provides comparative research and analysis of various open-source LMS. The study compares the various white board/video services, online and offline chat forums, file exchanges, internal email communications, online journal, and real-time chat features for each LMS. A comparison of six open-source LMS shows that Moodle and Atutor have an excellent communication tool with a friendly user interface. Details are easily accessible on the Moodle and Atutor web pages, ILIAS also makes the information easily accessible to potential customers. Claroline and Sakai are complex LMS web pages that make it harder to find information.

\subsubsection{Learning Management Systems for Higher Education - An Overview of Available Options for Higher Education Organizations (Dobre, 2015)}

This paper presents an overview, based on theoretical research, of available LMS options of the Institute of Higher Education (HEOs). The main purpose of this paper is to try to be as specific as possible within the short space of publication itself, covering the status of LMS in the context of ICT technology outstanding achievements recorded over the past two decades. Here we talk about the need for better and more organized courses, accurate record keeping and archiving, better communication, faster and more flexible modern testing tools for both teachers and students, the focus on the ongoing development, and not the last, the need to expand the education cycle. This is what LMS can do, to give ultimately one place for everything.

On the basis of the above research papers, a clear distinction can be made out between different LMS platforms, their features, and the services they provide. Following we present the detailed study of 10 LMS platforms.

\subsection{Open-source LMS}

A brief introduction of selected LMS from available open-source LMS is presented in this section. Official websites of the LMS as well several other sources from Crunchbase, 2021 have been used to gather the information.

\subsubsection{Moodle}

Moodle (Moodle, 2021) (Simanullang \& Rajagukguk, 2020) (Mealor, 2021) is an opensource online LMS which enables people in the education industry to create their own private website filled with dynamic courses for free. These courses impart learning to the 
students anytime and anywhere, according to their needs. Moodle.org is the original company where the Moodle LMS is developed and discussed (Reyes, et al., 2009; Mealor, 2021).

\begin{tabular}{|c|c|}
\hline \multicolumn{2}{|c|}{ Moodle https://docs.moodle.org/ } \\
\hline Vendor analysis & $\begin{array}{l}\text { - The foundation of Moodle LMS was laid in } 2001 . \\
\text { - The company's headquarters are located in Central Perth, } \\
\text { Western Australia. } \\
\text { - } \\
\text { founder idea of Moodle grew in the Australian outback. "Our } \\
\text { desert, and learned by distance education through radio", as quoted on } \\
\text { the official website of Moodle. }\end{array}$ \\
\hline & $\begin{array}{l}\text { The main aim of this platform is to empower educators to } \\
\text { improve our world and to instill a young generation with the core } \\
\text { values education, openness, respect, integrity, and innovation. } \\
\text { - The first version of Moodle was released in } 2002 \text { and the } \\
\text { current version of Moodle (Moodle 3.10.1 MOODLE_3101) was } \\
\text { released in 2021. }\end{array}$ \\
\hline Product analysis & $\begin{array}{l}\text { The platform claims to have more than } 213 \text { million users. Major } \\
\text { products of Moodle include Moodle LMS, Moodle App, Moodle } \\
\text { Workplace, Moodle Cloud, Moodle Education, and Certified } \\
\text { Integrations. } \\
\text { Moodle mainly targets schools, small universities, and research centers } \\
\text { (Reyes, et al., 2009) for the marketing of their products. Moodle is built } \\
\text { in PHP programming language. Moodle is usually installed on a Linux } \\
\text { server (Bri, Garcia, Coll, \& Lloret, 2009). The biggest advantage of } \\
\text { this platform is that it is open source under the GNU General Public } \\
\text { License. They have in total } 5 \text { packages with different pricing based } \\
\text { upon number of users and storage to choose from for their customers. }\end{array}$ \\
\hline
\end{tabular}

\subsubsection{Canvas}

Canvas (Canvas, 2021) is also one amongst the LMS which make the idea of online education possible. Canvas is built by a company named Instructure. 


\section{World Conference on EDUCATION and TEACHING}

\begin{tabular}{|c|c|}
\hline Canvas https:// & $\mathrm{Nw}$. instructure.com/en-au \\
\hline Vendor analysis & $\begin{array}{l}\text { - Canvas came into existence in 2008. The company's } \\
\text { headquarters are located in Salt Lake City, UT 84121, USA. } \\
\text { - The parent company Instructure was founded in } 2008 \text { by two } \\
\text { BYU graduate students, Brian Whitmer and Devlin Daley. } \\
\text { - They have a dream of elevating student success, amplify the } \\
\text { power of teaching, and inspire everyone to learn together. } \\
\text { - } \quad \text { urrent versions of Canvas include CanvasLive, Conferences, } \\
\text { CanvasCon } 2020 . \\
\text { - There have been } 722,443 \text { downloads in the last } 30 \text { days. }\end{array}$ \\
\hline Product analysis & $\begin{array}{l}\text { The platform claims to have more than } 5000 \text { customers. Major products } \\
\text { of Canvas include: } \\
\text { - K-12: Canvas LMS, MasteryConnect, Canvas Studio, Canvas } \\
\text { Catalog, Certica Assessment Content, Videri, Certify } \\
\text { - Higher ed: Canvas LMS, Canvas Studio, Canvas Catalog, } \\
\text { Program Assessment, Pathways } \\
\text { - Business: Bridge Learning \& Performance Management, } \\
\text { Corporate Canvas } \\
\text { Their target audience mainly include educational and corporate } \\
\text { organizations. Canvas is written in Ruby. Canvas performs best on } \\
\text { Chrome 87/88, Firefox 84/85, Edge 87/88, Respondus Lockdown } \\
\text { Browser, and Safari 13/14 (Macintosh only). }\end{array}$ \\
\hline
\end{tabular}

\subsubsection{ILIAS}

ILIAS (ILIAS, 2021) is a powerful LMS that meets all of your needs. This platform is helping small and large businesses, universities, schools and public authorities to create tailored, individual learning scenarios by using its integrating tools.

\begin{tabular}{|l|l|}
\hline ILIAS https://www.ilias.de/en/ \\
\hline Vendor analysis & $\begin{array}{l}\text { ILIAS was launched in } 1998 \text { and the company's headquarters } \\
\text { are located in Haren, Brussels Hoofdstedelijk Gewest, Belgium. } \\
-\quad \text { The mission of ILIAS is the creation of a flexible learning and } \\
\text { working environment with integrated tools which can help the students } \\
\text { as well as the teachers to learn and teach in the most efficient way. }\end{array}$ \\
\hline Product analysis & $\begin{array}{l}\text { The company claims to serve more than 0.5 million users worldwide. } \\
\text { Their main products include ILIAS for universities, ILIAS for } \\
\text { companies, ILIAS for schools, and ILIAS for the public service. They } \\
\text { target mostly university and school (Reyes, et al., 2009) students and } \\
\text { teachers. ILIAS is written in php and can be installed cross platforms. }\end{array}$ \\
\hline
\end{tabular}

\subsubsection{OpenOlat}

OpenOlat (OpenOlat, 2021) is a web-based LMS for teaching, education, assessment and communication. OpenOlat platform, when installed, can be adapted to organizational needs and integrated into existing IT structures. The company behind the platform is Frentix. 


\section{World Conference on EDUCATION and TEACHING}

\begin{tabular}{|c|c|}
\hline \multicolumn{2}{|c|}{ OpenOlat https://www.openolat.org } \\
\hline Vendor analysis & $\begin{array}{l}\text { - } \\
\text { - } \\
\text { Trentix was launched in } 2006 . \\
\text { offers e-learning and software development services. } \\
\text { - } \quad \text { They are specialized in the open-source LMS OpenOlat and } \\
\text { Java/JavaScript based web and mobile applications. }\end{array}$ \\
\hline Product analysis & $\begin{array}{l}\text { Version } 10 \text { of OpenOlat was released recently. Their main products } \\
\text { include: } \\
\text { - For companies: OpenOlat offers connections to existing } \\
\text { systems, employee reviews and high performance to replace expensive } \\
\text { and timeconsuming classroom training. } \\
\text { - For schools: Whether simple distribution of documents, } \\
\text { assignments, or the execution of exams - OpenOlat offers countless } \\
\text { possibilities to support school processes thanks to the scalable course } \\
\text { design. } \\
\text { - For universities: Thanks to the catalog module, the extensive } \\
\text { course kit, the recourse-proof test system, and the extremely scalable } \\
\text { system architecture, OpenOlat is perfect for use at colleges and } \\
\text { universities. - For urban authorities or state institutions: They are also } \\
\text { the focus here on data protection requirements and the secure } \\
\text { infrastructure of OpenOlat. } \\
\text { OpenOlat is written in java and can be installed on Windows, Linux, } \\
\text { macOS operating systems. OpenOlat is open source, licensed by } \\
\text { Apache License } 2.0 \text { with lowest fee for hosting of } \$ 250 / \text { month for } 250 \\
\text { users. }\end{array}$ \\
\hline
\end{tabular}

\subsubsection{Blackboard LMS}

Blackboard (Blackboard, 2021) is also one of the leading EdTech companies offering higher education, $\mathrm{K}-12$, businesses and government clients worldwide. The objective of this platform is to connect a deep understanding of education with the power of technology to continuously push the boundaries of learning to revolutionise the world.

\begin{tabular}{|l|l|}
\hline Blackboard LMS https://www.blackboard.com/teaching-learning \\
\hline Vendor analysis & - Blackboard LMS was launched in 1997. \\
\hline Product analysis & $\begin{array}{l}\text { The company's headquarters are located in the USA. } \\
\text { The company claims to have 100 million learners and 20 years } \\
\text { of experience. }\end{array}$ \\
& $\begin{array}{l}\text { Version 6.0 was released recently. Their main products include } \\
\text { Blackboard Collaborate, Blackboard LMS for Business, and } \\
\text { Blackboard Analytics for Learn. They mostly target corporate, } \\
\text { university, big government. Blackboard LMS can be installed on } \\
\text { Windows 8, Windows 10, Mac OS 10.12, Mac OS 10.13, Mac OS } \\
\text { 10.14 (Itmazi, Gea, Paderewski-Rodríguez, \& Vela, 2005) Operating } \\
\text { systems. }\end{array}$ \\
\hline
\end{tabular}




\section{World Conference on EDUCATION and TEACHING}

\subsubsection{Dokeos}

Dokeos LMS (DOKEOAS, 2021) is a complete eLearning suite with an easy-to-use writing system and robust reporting that allows you to easily create and manage a training and skills curriculum. Dokeos LMS helps more than 2,000 organizations worldwide to manage online learning activities, collaborations, and compliance.

\begin{tabular}{|c|c|}
\hline Dokeos https:// & v.dokeos.com/learning-management-system-lms \\
\hline Vendor analysis & $\begin{array}{l}\text { - Dokeos, a developer and publisher of e-learning solutions, is } \\
\text { first and foremost a service company. }\end{array}$ \\
\hline & $\begin{array}{l}\text { Since } 1999 \text {, it has supported companies, training organizations, } \\
\text { as well as medical teams, in developing customized training and testing } \\
\text { solutions. }\end{array}$ \\
\hline & $\begin{array}{l}\text { - It was founded in } 1999 \text { and the company's headquarters are } \\
\text { located in France. }\end{array}$ \\
\hline Product analysis & $\begin{array}{l}\text { The latest version of Dokeos LMS is 3.0. The main products include } \\
\text { Dokeos Manager, Dokeos Author, Dokeos Evaluation, Dokeos } \\
\text { Games, Dokeos Live, Dokeos Shop, and Dokeos WebTV. }\end{array}$ \\
\hline
\end{tabular}

\subsubsection{TalentLMS}

TalentLMS (TalentLMS, 2021) is a cloud-based LMS that helps small and midsize businesses provide training programs. Managers can create a community homepage and customize their portal to include branding, such as logos, colors, and custom background.

\begin{tabular}{|l|l|}
\hline TalentLMS https://www.talentlms.com/platform \\
\hline Vendor analysis & $\begin{array}{l}\text { TalentLMS is ideal for small to midsize companies training } \\
\text { employees, partners, or customers. } \\
\text { Customers who have achieved success with TalentLMS are in } \\
\text { technology, manufacturing, healthcare, professional services, and } \\
\text { marketing. They include Galvanize, Formlabs, Rosetta Stone, and } \\
\text { Infosys. } \\
-\quad \text { TalentLMS is an award-winning cloud-based solution ideal for } \\
\text { delivering engaging online training. It was founded in 2012 and the } \\
\text { company's headquarters are located in San Francisco, California, } \\
\text { USA. }\end{array}$ \\
\hline Product analysis & $\begin{array}{l}\text { The latest version of TalentLMS is Summer 2020 Update. The main } \\
\text { products include Onboarding Training, Compliance Training, } \\
\text { Customer Training, Partner Training, Sales Training, Marketing, } \\
\text { Training, and Remote Workforce Training. }\end{array}$ \\
\hline
\end{tabular}

\subsubsection{Atutor}

Atutor (A Tutor, 2021) is a free, open-source LMS that enables small and large organizations to create e-learning content and conduct online courses. Instructors are able to compile, package, and distribute web-based instructional content, import pre-prepared content and create lessons online, while providing students with an accessible, flexible and social learning environment. 


\section{World Conference on EDUCATION and TEACHING}

\begin{tabular}{|l|l|}
\hline Atutor https://atutor.github.io/ \\
\hline Vendor analysis & $\begin{array}{l}\text { Atutor is used to develop and deliver online courses. } \\
\text { Managers can install or update Atutor in minutes, upgrade } \\
\text { custom themes to give Atutor a new look, and easily extend its } \\
\text { functionality with feature modules. } \\
-\quad \text { Teachers can quickly integrate, feed, and distribute web-based } \\
\text { educational content, easily import pre-prepared content, and conduct } \\
\text { their online lessons. } \\
-\quad \text { Students learn in an accessible, adaptive, social learning } \\
\text { environment. } \\
-\quad \text { It was founded in 2002 and the company's headquarters are } \\
\text { located in London. }\end{array}$ \\
\hline Product analysis & $\begin{array}{l}\text { The latest version of Atutor is 2.2.4 adding course gamification, new } \\
\text { user orientation, and a variety of other fixes and refinements. The main } \\
\text { products include Acontent LCMS and Developers. A unique feature is } \\
\text { that is useful to visually impaired and disabled learners (Reyes, et al., } \\
\text { 2009). }\end{array}$ \\
\hline
\end{tabular}

\subsubsection{Forma}

Forma LMS (FormaLMS, 2021) is an award-winning learning program, used to manage and deliver online training courses. Designed for corporate training, born to fit company needs and processes. For easy integration with any intranet software, extend the functionality with a variety of plug-ins.

\begin{tabular}{|l|l|}
\hline Forma https://www.formalms.org/ \\
\hline Vendor analysis & $\begin{array}{l}\text { Forma LMS is an Italian software company that was founded } \\
\text { in 2005 and offers a software title called Forma LMS. } \\
-\quad \text { Forma LMS offers training in writing, webinars, live online, } \\
\text { and in person. } \\
-\quad \text { Forma LMS offers a free version with a free trial. }\end{array}$ \\
\hline Product analysis & $\begin{array}{l}\text { Forma LMS is a LMS software which includes features such as } \\
\text { academic / education, asynchronous learning, blended learning, } \\
\text { certification management, corporate/business, eCommerce, } \\
\text { gamification, gradebook, mobile learning, skills tracking, social } \\
\text { learning, synchronous learning, training companies, video } \\
\text { conferencing, e-learning companies, SCORM compliance, and learner } \\
\text { portal. }\end{array}$ \\
\hline
\end{tabular}

\subsubsection{Sakai CLE}

Sakai (SakaiLMS, 2021) was developed as an open-source software as a community effort, run by the Apereo Foundation, a member-based non-profit organization. The constitution promotes the use and development of Sakai in the same open, ethical manner in which it was created. It encourages community building between individuals, academic institutions, nonprofit and commercial organizations and provides its members with an institutional framework for their projects. It works to promote broad acceptance of social approaches and open standards for software solutions within the academic and research communities. 


\section{World Conference on EDUCATION and TEACHING}

\begin{tabular}{|l|l|}
\hline Sakai CEI https://www.sakailms.org/ \\
\hline Vendor analysis & $\begin{array}{l}\text { Sakai } 1.0 \text { was released in 2005, and it was adopted by all } \\
\text { participating universities. }\end{array}$ \\
& $\begin{array}{l}\text { For example, Indiana University has transferred all of its } \\
\text { legacy programs to Sakai. It was founded in 2004. }\end{array}$ \\
\hline Product analysis & $\begin{array}{l}\text { The company's headquarters are located in the US. } \\
\text { Main Features: }\end{array}$ \\
& $\begin{array}{l}\text { provide real performance. In addition to the basic tools distributed } \\
\text { with Takai, several important third-party tools are available and web } \\
\text { developers can write their own additional tools in a language of their } \\
\text { own choice. }\end{array}$ \\
& $\begin{array}{l}\text { For playing SCORM packages third-party tools are available. } \\
\text { LTI used for integrating external web applications. }\end{array}$ \\
\hline
\end{tabular}

\section{Detailed analysis}

After a detailed analysis of these platforms, we are going ahead with the 6 LMS Moodle, ILIAS, Blackboard, Dokeos, Atutor, Sakai platforms, as shown in Tab. 1. We researched for various online LMS and found these 6 are the most popular and widely used platforms across the globe. According to a study done by researchers, Moodle is the most user-friendly and flexible free open-source courseware product available all over the world, followed by ILIAS and then Atutor (Al-Ajlan, 2012), while Dokeos stands at the mid position (Reyes, et al., 2009). Further, we researched about the vendor and product details of these platforms and found that not much data is provided by the developers over the site for us to get more details about the platforms.

Table 1: Comparison of the features, also summarized in (Bhattacharyya, 2020) (Al-Ajlan, 2012)

\begin{tabular}{|l|l|c|c|c|c|c|c|}
\hline Name/feature & $\begin{array}{l}\text { Description } \\
\text { of the feature }\end{array}$ & Moodle & ILIAS & $\begin{array}{l}\text { Black- } \\
\text { board }\end{array}$ & Atutor & Dokeos & $\begin{array}{l}\text { Sakai } \\
\text { SLE }\end{array}$ \\
\hline Communication tools & $\begin{array}{l}\text { Rich-text and } \\
\text { media can be } \\
\text { used in class } \\
\text { discussion }\end{array}$ & Yes & Yes & Yes & Yes & Yes & Yes \\
\hline Discussion forum & $\begin{array}{l}\text { A file } \\
\text { management } \\
\text { system for } \\
\text { courses and } \\
\text { student work }\end{array}$ & Yes & Yes & Yes & Yes & $\begin{array}{c}\text { 3rd } \\
\text { party } \\
\text { plug-in }\end{array}$ & No \\
\hline File management & $\begin{array}{l}\text { Real time video } \\
\text { calling }\end{array}$ & $\begin{array}{c}3 \text { rd } \\
\text { party } \\
\text { plug-in }\end{array}$ & Yes & Yes & No & Yes & No \\
\hline $\begin{array}{l}\text { Video } \\
\text { conferencing }\end{array}$ & & & & & \\
\hline
\end{tabular}


World Conference on EDUCATION and TEACHING

France, Paris

\begin{tabular}{|c|c|c|c|c|c|c|c|}
\hline Chat & $\begin{array}{l}\text { Real-time } \\
\text { textbased } \\
\text { communication } \\
\end{array}$ & $\begin{array}{c}\text { 3rd } \\
\text { party } \\
\text { plug-in }\end{array}$ & Yes & Yes & Yes & Yes & Yes \\
\hline $\begin{array}{l}\text { Online } \\
\text { journal/notes }\end{array}$ & $\begin{array}{l}\text { Real-time writing } \\
\text { pad }\end{array}$ & Yes & Yes & No & No & No & Yes \\
\hline $\begin{array}{l}\text { Multilingual } \\
\text { service }\end{array}$ & $\begin{array}{l}\text { Courses available } \\
\text { in multiple } \\
\text { languages }\end{array}$ & Yes & Yes & $\begin{array}{c}\text { 3rd } \\
\text { party } \\
\text { plug-in }\end{array}$ & $\begin{array}{c}\text { 3rd } \\
\text { party } \\
\text { plug-in }\end{array}$ & Yes & Yes \\
\hline \multicolumn{8}{|l|}{ Productivity tools } \\
\hline Bookmarks & \begin{tabular}{|l|} 
Bookmarks for \\
courses or notes
\end{tabular} & No & Yes & Yes & No & No & Yes \\
\hline $\begin{array}{l}\text { Calendar/progress } \\
\text { review }\end{array}$ & $\begin{array}{l}\text { Integration of a } \\
\text { calendar to } \\
\text { organize courses }\end{array}$ & Yes & Yes & Yes & Yes & Yes & Yes \\
\hline Offline service & $\begin{array}{l}\text { Notes and } \\
\text { courses available } \\
\text { offline }\end{array}$ & Yes & Yes & Yes & Yes & Yes & Yes \\
\hline Analysis & $\begin{array}{l}\text { Data reports } \\
\text { about usage in } \\
\text { the system, } \\
\text { grades etc. }\end{array}$ & Yes & Yes & Yes & Yes & No & Yes \\
\hline Group work & $\begin{array}{l}\text { Collaborative } \\
\text { work tools }\end{array}$ & Yes & Yes & Yes & Yes & Yes & Yes \\
\hline Assignments & $\begin{array}{l}\text { Some way to } \\
\text { assign work and } \\
\text { receive } \\
\text { completed work } \\
\end{array}$ & Yes & Yes & Yes & Yes & Yes & Yes \\
\hline $\begin{array}{l}\text { Grades and } \\
\text { gradebook }\end{array}$ & $\begin{array}{l}\text { Specifying a } \\
\text { framework for } \\
\text { how evaluations } \\
\text { translate to } \\
\text { grades }\end{array}$ & Yes & Yes & Yes & Yes & $\begin{array}{c}\text { 3rd } \\
\text { party } \\
\text { plug-in }\end{array}$ & Yes \\
\hline Cheating control & $\begin{array}{l}\text { Plagiarism } \\
\text { checker }\end{array}$ & No info & $\begin{array}{l}\text { No } \\
\text { info }\end{array}$ & $\begin{array}{l}\text { No } \\
\text { info }\end{array}$ & $\begin{array}{l}\text { No } \\
\text { info }\end{array}$ & No info & $\begin{array}{l}\text { No } \\
\text { info }\end{array}$ \\
\hline Common groups & $\begin{array}{l}\text { Build specific } \\
\text { groups of } \\
\text { students for } \\
\text { collaborative } \\
\text { work, discussions } \\
\text { etc. }\end{array}$ & Yes & Yes & Yes & Yes & Yes & Yes \\
\hline Attendance tool & $\begin{array}{l}\text { Attendance can } \\
\text { be tracked by } \\
\text { teachers }\end{array}$ & Yes & No & Yes & No & No & Yes \\
\hline
\end{tabular}


World Conference on EDUCATION and TEACHING

\begin{tabular}{|l|l|c|c|c|c|c|c|}
\hline Notification & $\begin{array}{l}\text { Timely updates } \\
\text { regarding the } \\
\text { courses, tests etc. }\end{array}$ & Yes & Yes & Yes & Yes & Yes & Yes \\
\hline Modules & $\begin{array}{l}\text { Courses are } \\
\text { separated into }\end{array}$ & Yes & Yes & Yes & Yes & Yes & Yes \\
\hline & $\begin{array}{l}\text { modules to } \\
\text { organize content }\end{array}$ & & & & & & \\
\hline
\end{tabular}

\section{Support and maintenance tools}

\begin{tabular}{|c|c|c|c|c|c|c|c|}
\hline Account & $\begin{array}{l}\text { Back-end admin } \\
\text { of the software }\end{array}$ & Yes & Yes & Yes & Yes & Yes & Yes \\
\hline Training & $\begin{array}{l}\text { Help center of } \\
\text { platform }\end{array}$ & Yes & Yes & Yes & Yes & Yes & Yes \\
\hline Consulting & & Yes & Yes & Yes & No & Yes & Yes \\
\hline Authentication & & Yes & Yes & Yes & Yes & Yes & Yes \\
\hline \begin{tabular}{|l|} 
Customizable \\
themes
\end{tabular} & $\begin{array}{l}\text { Various types of } \\
\text { templates app }\end{array}$ & Yes & Yes & Yes & Yes & Yes & Yes \\
\hline Online grading & & Yes & Yes & Yes & Yes & Yes & Yes \\
\hline Student tracking & Progress tracker & Yes & Yes & Yes & Yes & Yes & Yes \\
\hline $\begin{array}{l}\text { Content } \\
\text { sharing/reuse }\end{array}$ & $\begin{array}{l}\text { Sharing of files } \\
\text { over the platform }\end{array}$ & Yes & $\begin{array}{c}\text { 3rd } \\
\text { party } \\
\text { plug-in } \\
\end{array}$ & Yes & Yes & Yes & Yes \\
\hline SIS imports & \begin{tabular}{|l|} 
Student \\
information can \\
be pulled from an \\
SIS \\
\end{tabular} & Yes & No & Yes & $\begin{array}{c}\text { 3rd } \\
\text { party } \\
\text { plug-in }\end{array}$ & $\begin{array}{c}\text { 3rd } \\
\text { party } \\
\text { plug-in }\end{array}$ & Yes \\
\hline SCORM & $\begin{array}{l}\text { Sharable content } \\
\text { object reference } \\
\text { model }\end{array}$ & Yes & Yes & Yes & Yes & Yes & Yes \\
\hline Speed Grader & $\begin{array}{l}\text { A whole class } \\
\text { grading function } \\
\text { for teachers }\end{array}$ & Yes & Yes & Yes & No & Yes & Yes \\
\hline
\end{tabular}

\section{Exclusive features}

\begin{tabular}{|l|l|c|c|c|c|c|c|}
\hline Custom learning & $\begin{array}{l}\text { Courses } \\
\text { according to } \\
\text { students' interest }\end{array}$ & Yes & No & No & Yes & Yes & No \\
\hline Canvas commons & $\begin{array}{l}\text { A resource } \\
\text { repository and } \\
\text { sharing platform }\end{array}$ & No & No & No & No & No & No \\
\hline
\end{tabular}

\section{Conclusion and scope of future research}

This paper carried out an evaluation of available open-source LMS. It is evident from the research, as expected, that no single LMS is able to provide a complete feature set. But the goal of this paper was to provide this gap analysis, so that the potential customers and users can select the respective LMS as per their needs. This paper also provides cues to LMS providers 


\section{World Conference on EDUCATION and TEACHING}

on what their competitors are doing and how they can improve the competitive advantage of their LMS by introducing new features.

Future research can be done on the usability, adaptability, and performance of these LMS in the current scenario of the pandemic. A market study of these platforms can be carried out. A survey regarding the product analysis can be done for new entrants in the market. The education industry is an ever-growing industry with new technologies always coming up and transforming our lifestyles. There is a need to make the education system more learningoriented so that students not only know how to make a living but also how to live. Future researches can be done on how to make learning for students more effective, and more project oriented. In online education, a major challenge is the lack of practical knowledge and this area still needs to be explored and researched about. Also, another major concern of online education is the increased screen time which can adversely affect the eyes of students. This can also be a good research topic of how LMS platforms can be designed so that students gain more practical knowledge and with a limited screen time.

\section{References}

A Tutor. (2021, March 12). A Tutor - Expert Tutoring Advice. Retrieved from https://atutor.ca/

Al-Ajlan, A. S. (2012). A Comparative Study Between E-Learning Features. In E. Pontes, A. Silva, A. Guelfi, \& S. Takeo Kofuji, Methodologies, Tools and New Developments for E-Learning. IntechOpen.

Anaraki, F. (2004). Developing an effective and efficient eLearning platform. International Journal of the Computer, the Internet and Management.

Bhattacharyya, A. R. (2020). Do Learning Management Systems Really Manage Learning? University of Texas.

Blackboard. (2021, March 12). Learning Managment Systems (LMS) \& Software| Blackboard. Retrieved from https://www.blackboard.com/teaching-learning/learning-management

Bri, D., Garcia, M., Coll, H., \& Lloret, J. (2009). A Study of Virtual Learning Environments. WSEAS Transactions on Advances in Engineering Education.

Canvas. (2021, March 12). Canvas LMS | Learning Managment System| Instructure. Retrieved from https://www.instructure.com/canvas

Cavus, N., \& Zabadi, T. (2014). A Comparison of Open Source Learning Management Systems. Procedia - Social and Behavioral Sciences, 143, 521-526.

Crunchbase. (2021, March 12). Crunchbase: Discover innovative companies and people behind them. Retrieved from https://www.crunchbase.com/

de Oliveira, P. C., de Almeida Cunha, C. J., \& Nakayama, M. K. (2015). Learning Management Systems (LMS) and e-learning management: an integrative review and research agenda. Journal of Information Systems and Technology Management, 13(2).

Dobre, I. (2015, May 5). Learning Management Systems for Higher Education - An Overview of Available Options for Higher Education Organizations. Procedia - Social and Behavioral Sciences, 180, 313-320. 
World Conference on EDUCATION and TEACHING

DOKEOAS. (2021, March 12). DOKEOS - LMS \& E-learning Suite for growing companies. Retrieved from https://www.dokeos.com/

Fathema, N., Shannon, D., \& Ross, M. (2015, June). Expanding The Technology Acceptance Model (TAM) to Examine Faculty Use of Learning Management Systems (LMSs) In Higher Education Institutions. MERLOT Journal of Online Learning and Teaching, 11(2).

FormaLMS. (2021, March 12). Forma LMS Features. Retrieved from https://www.formalms.org/features.html

Hevner, A. R., \& Chatterjee, S. (2010). Design Research in Information Systems: Theory and. Springer Science and Business Media.

ILIAS. (2021, March 12). ILIAS Uni Freiburg - ILIAS e-Learning Platform. Retrieved from https://ilias.uni-freiburg.de/login.php?lang=en

Itmazi, J., Gea, M., Paderewski-Rodríguez, P., \& Vela, F. L. (2005). A comparison and evaluation of open source learning managment systems. AC 2005, Proceedings of the IADIS International Conference on Applied Computing. Algarve, Portugal.

Karthik, S. (2018, May 4). Comparative analysis of various learning management systems (LMS) for academe in India. International Journal of Innovative Research in Management Studies (IJIRMS), 8-12.

Khan, I. A. (2020). Electronic Learning Management System: Relevance, Challenges and Preparedness. JETIR.

Kulshrestha, T., \& Kant, A. R. (2013). Benefits of Learning Management System. International Journal of Computer Science \& Engineering Technology (IJCSET), 1153-1164.

Mealor, S. (2021). Using Moodle in Small to Medium Sized Business. iBook. Retrieved March 12 , 2021 ,

from https://www.moodlebites.com/pluginfile.php/5179/mod_page/content/2/Using\%20Mo odle\%20in\%20small\%20to\%20medium\%20sized\%20business.pdf

Moodle. (2021, March 12). Moodle - Open source learning platform | Moodle.org. Retrieved from https://moodle.org/

OpenOlat. (2021, March 12). OpenOlat - infinite learning. Retrieved from https://olat.vcrp.de/dmz/

Reyes, N. R., Candeas, P. V., Galan, S. G., Viciana, R., Canadas, F., \& Reche, P. J. (2009). Comparing open-source e-learning platforms from adaptivity point of view. EAEEIE Annual Conference. Valencia.

SakaiLMS. (2021, March 12). Sakai Learning Management System | Higher Education. Retrieved from https://www.sakailms.org/

Simanullang, N. H., \& Rajagukguk, J. (2020, February). Learning Management System (LMS) Based On Moodle To Improve Students Learning Activity. Journal of Physics Conference Series. 
World Conference on EDUCATION and TEACHING

Subramanian, P., Zainuddin, N., Alatawi, S., Javabdeh, T., \& Hussin, A. R. (2014). A Study of Comparison between Moodle and Blackboard based on Case Studies for Better LMS. Journal of Information Systems Research and Innovation.

TalentLMS. (2021, March 12). TalentLMS: Cloud LMS Software - \#1 Online Learning Platform. Retrieved from https://www.talentlms.com/ 